\title{
Analysis of Community and Local Politics The Challenge of the Horizontal Conflict (A Case Study in Kampar Riau, A Constructive Critical Thinking from the Perspective of Political Anthropology)
}

\section{Syafrizal}

Faculty of Social and Political Sciences, Universitas Muhammadiyah Sumatera Utara, Indonesia syafrizal@umsu.ac.id

\begin{abstract}
This paper wants to critically explain constructively from the perspective of political anthropology, namely one thought on one of the social realities that develop in society Kampar Riau. Society is a group of people who live in one area for a certain period of time, who have emotional attachments and have a common goal. In that context, it is not uncommon for people to incarnate themselves into various situations, including in terms of politics and society. The phenomenon of folklore and local politics is a form of democratic life that is guaranteed by the laws of the Indonesian state. Everyone has their own life history. Talking about humans would be tantamount to talking about who is the owner and creator of all cultures. Humans create their experiences since childhood in the environment in which they were born. Community phenomenon is one of the oldest that characterizes a person's attitude, behavior pattern, which consciously or unconsciously will be incarnated in the long process of his life wherever that person takes part as an adult, such as taking part in an organization, company, or in a certain political party.
\end{abstract}

Keywords

community; local politics; conflict

\section{Introduction}

In this introductory section will describe the phenomena that are common about the existence of diversity in Indonesia. The discussion on the problem of ethnic pluralism in Indonesia until now is still unfinished and will continue in the future. The challenge of gaining an emotional sense of being one nation still includes one of the serious threats in our country. The challenge of national unity, national integration will become more complicated if the government through various policies is not able to explain how the concept of the state of unity that is desired since Indonesia's independence. Hildred Geertz (1981), said that in Indonesia there are more than 300 different ethnic groups, each with its own cultural identity.

In addition, more than 200 special languages, a variety of beliefs, as well as economic adaptations that are so different. Junus Melalatoa (1995), that it is known that there are no less than 500 tribes that inhabit the territory of the country agreed together called the Republic of Indonesia, they inhabit about 17,000 islands large and small. The above statement, supported by Hassan Shadily (1961), that Indonesia consists of approximately 300 tribes such as Javanese tribes, Batak tribes, Sundanese tribes, Madurese tribes, Minangkabau tribes and so on.

In addition to ethnic known in anthropological literature there are also many other ethnic unknown grouped randomly into certain ethnic groups, such as ethnic Gayo, Alas, 
tamiang, aneuk jamee, Simeulue, kluet, and gumbak Cadek in Aceh, the Ocu in Kampar Riau, rao in West Sumatra, and badui, and osing in West Java. The true number of ethnic pluralism in Indonesia has so far not been known, by R. Kennedy 1950, (in Zulyani Hidayah 1996), through the HRAF (Human Relations Area File) agency from Yale University in the United States, which is said to have complete ethnic data. Worldwide, at most only 1/3 (third) of all ethnic groups in Indonesia, although R. Kennedy's efforts were continued by FM Lebar (1972), but did not provide a significant change.

One thing we must realize is that as a country that has a very diverse regional and demographic structure, of course, specific management methods are needed. Without proper management, it will be disastrous for the existence of the state. An aspect that is related to what is stated above is the existence of the smallest elements that exist, which are then known as tribal groups, one clan, clans on behalf of one clan, and others.

The forms of these small groups are then also referred to as people or groups in their dynamics which will penetrate life in all aspects of life. We can see the dynamics of social groups in society in the current decade, sometimes we are amazed and almost do not believe that a people or clan or those who are characterized by it, have shown and are able to express themselves as unique that is taken into account, for example in political events, such as Puja Kesuma (Puja Kesuma). Javanese sons of Sumatran descent) on the island of Sumatra, HIKMA (mandailang family association) in Medan, the Kampar Family Association (IKK) in Medan and its surroundings, and various forms of groups that exist on the basis of one group or group.

The emergence of this kind of phenomenon is not really the types of our society, especially when it is associated with involvement in political aspects, both nationally and locally. Precisely what has been so far is how the clan or clan is more likely to take care of matters relating to the relationship between clan members, family relations with other clans, marriage and others that are inward. According to Manao (2020), In Indonesia, the political elite is trying to build the image to gain sympathy from the community, so that the intensity of competition in the public space, including in the media looks very clear. Azhar (2018) stated that the political struggle is not only related to the actual condition of each political party, but also related to the candidates.

It can be said that the people's choice to participate in practical political aspects is something that must be known what aspects allow this to happen. Of course, there must be aspects that influence it so that it carries out such a radical metamorphosis process in the sense that people have made a very big leap into other worlds that were previously considered not their worlds. Paying attention to and understanding deeply these dynamics, this issue has become one of the issues that has attracted the interest of researchers. There are at least two reasons that can be put forward, so that this issue is of interest to the reviewer, including:

First, the current issue of racism seems to have the appeal to be studied by various other researchers, who will contribute to the resolution of racial issues in various places. Racial conflict will have an impact on the development of a nation. Therefore, this issue is important to find out through research activities because it is considered to have a huge influence on nation building (nation building) in Indonesia.

Ontologically, in the popular mind, Indonesian society has always been seen as a plural society consisting of various ethnicities, languages, and religions, as well as differences that are visible rather than physical such as skin color, hair color and face, as well as various human characters. . Yet, in essence, none of these groups are homogeneous, they are made up of groups with different languages and religions. 
For example, Javanese in general, Javanese are seen as Muslims and speak Javanese, but in fact they have their own local dialect and their Islam can also be divided into orthodox Islam and popular Islam (Budiono Kusumohamidjojo 2000). This can happen either to any other ethnic group, due to the natural influence of the local environment as well as the process of social interaction with other groups.

Second, as a form of social phenomenon, this study can be reviewed from several perspectives, each of which can also provide its own interpretation. As a strategic study, the researcher will try to do research on anything that can give meaning, as well as real findings to reduce and find macro and micro solutions and politics.

The entire description presented above, directly or indirectly tells and describes the dynamics of race or ethnicity that exists in Kampar Riau in various phenomena of change, including the subject of football in politics, especially local politics. Various social institutions, values, as well as methods of social relations, are always based on local cultural values.

\section{Literature Review}

There are several main aspects that will be described in detail in this section, including aspects related to racism and political aspects in general as well as local politics.

\subsection{Definition of Racism}

Racism in the KBBI dictionary has the meaning of kinship, kinship, group, clan, tribal way (grouped according to tribe); tribal. A more dynamic understanding that racism can also be defined as an organization based on ethnicity. To gain a further understanding of the tribe, as the following description.

There are several descriptions of the Malaysian version of racism issues that Malaysia has implemented several ways to curb racism, among others:

a. Disputes

1. misunderstandings between races can be avoided through the planning of several programs that require each race to be involved in them.

2. the program implemented should include activities that have elements of unity. Programs such as "Program 1 Malaysia", insight school development program and many other programs need to be multiplied.

3. other programs such as open houses for the festivals of each ethnic group practiced in our country should also be expanded throughout the country.

4. parents need to encourage children to mix with the multi-ethnic community. Our society also needs to socialize, share opinions and build groups with other racial communities.

5. therefore, we must always be careful not to be prejudiced against other races in order to avoid selfishness.

b. Agreement between the Races

Malaysia is a unique country where it is a country with a lot of people who inhabited by the Malays, Chinese and Indians who are the country's three major races in Malaysia. The total population of Malaysia until 2010 is estimated to exceed 28.25 million people. Out of this population, the Malay Bumi puteras comprise 50.4\%, China 23.7\%, India $7.1 \%$, and the remaining races of non-Malay Bumiputera and others. Since gaining its independence on August 31, 1957, many challenges and trials have been passed by the country and the most important of them is to create unity among these races. 


\section{c. Language and How to Communicate}

Malay is the national language and official language of Malaysia. Therefore, the official language serves as a channel used by all Malaysians. However, the problem in the opposite of most of the non-Malays are still not able to speak properly. This is because the mother tongue used since childhood has made it difficult for most of them to understand the official language well.

d. Suggestions And Influence From Parents

The proverbial bamboo bends let it be from its shoots. The first person to approach children is the parents. Therefore the thoughts and behavior of children will be influenced by their parents. For example their children will be given about racial issues since childhood, most parents in Malaysia still have a wrong perception of racial issues such as the May 13 incident that occurred in 1969, namely the riots that took place in Malaysia, then they will giving the fact that greetings will influence children towards other races in Malaysia. This makes unity and agreement between races and nations difficult to achieve.

e. Programs and Policies of Racial Associations

Have Been Politicized Every Malaysian should see and interpret national programs and policies that are implemented rationally, objectively, wisely and responsibly. Think as a true Malaysian, adhere to the principle of upholding the sky where the earth is trodden. Educational programs for example that are introduced are an investment to secure the future.

Apart from the picture of the racist treatment carried out by Malaysia, the racist treatment carried out by the Indonesian government is no less great. As stated in the background section of the issue, it is known that there are no less than 500 tribes inhabiting the territory of this jointly agreed state called the Republic of Indonesia, they inhabit about 17,000 islands large and small (Junus Melalatoa 1995).

The term community within certain boundaries can refer to the residents of a hamlet, village, city, tribe or nation. In the sociological perspective, the hamlet or village community can be distinguished from the wider community (society) through the depth of mutual interest (a community of interest) or by a high level of interaction (an attachment community). Community members have common needs.

Furthermore, Cahya Dicky Pratama (2020), that a community is a unit or social unit that is organized in groups with common interests (communities of common interest), both functional and territorial. The term community within certain boundaries can refer to the residents of a hamlet (hamlet or village), village, city, tribe or nation.

In the sociological perspective, the community can be distinguished from the wider society (society) through the depth of common concern (a community of interest) or by a high level of interaction (an attachment community). Community members have common needs. The characteristics of a community are that its members participate and are directly involved in an activity. The point is that all member efforts are integrated with local government efforts to improve living standards. In addition, a community also has a specific locality or residence.

A similar picture is also put forward by Parta Ibeng (2021), that basically this group is people who have the same interests and also have several bases of interaction. They are bound to each other by a series of special social relationships. These groups can also be organized strictly and long -term, but there are also liquid and only temporary. The more members in the group, the less chance there will be of a deep social interaction among the 
members of the group. Conversely, if the smaller the number of members in a group, then the greater the chance for a deep social interaction between fellow group members.

To get a more detailed understanding of this, the following are some opinions of experts, including:

1) Merton, this group is a group of people who interact with each other in accordance with an established pattern, while in the group there is a sense of solidarity due to the shared values and also because of the shared responsibilities.

2) Homans (1950), that this group is a number of individuals who communicate with each other in a certain period of time that the number is also not too much, so that it provides an opportunity for all members to communicate directly.

3) Joseph De Vito (1997), this group is a group of individuals who are related to each other who have a common purpose and there is an organization or structure between them. Within the group are developed norms that are considered to be the basis for the behavior of its members.

In addition to the definition of the Ibeng Party group (2021), it also states that the group consists of several types, including:

1) Primary group, is a group with only a small number of members, although not every group with a few members is a primary group. The relationship between these members has a personal nature (to know each other personally) and is also deep, which is characterized by cooperation, often meeting face to face for a long time, so that it can / can build a deep emotional involvement. The purpose of this primary group is to build a personal relationship itself. Although sometimes there is a conflict, each of the members of the primary group will show genuine concern for the welfare of fellow members. So the relationship in this primary group is informal, intimate / intimate, personal, and also total. Examples are: (a) family, (b) group of friends, (c) playmates.

2) Secondary group, is a group that has many members. The relationship between these members also has an impersonal nature (do not know each other personally), which is more colored by competition, and rarely meets face to face for a long time, so they cannot build emotional relationships properly.

The relationship in this secondary group has impersonal, partial, formal nature, and is also based on the benefit of the group alone. Examples of secondary groups include: (a) labor organizations, (b) universities, (c) schools.

Table 1. Difference between Primary and Secondary Group

\begin{tabular}{|l|c|l|c|}
\hline No & $\begin{array}{c}\text { Primary Group (Primary } \\
\text { Group) }\end{array}$ & No & $\begin{array}{c}\text { Secondary Group (Scundery } \\
\text { Group) }\end{array}$ \\
\hline 1 & Generally small & 1 & Generally large \\
\hline 2 & $\begin{array}{c}\text { Relatively long-term } \\
\text { interaction }\end{array}$ & 2 & Relative to short term \\
\hline 3 & $\begin{array}{c}\text { Have a very close } \\
\text { relationship }\end{array}$ & 3 & Less familiar \\
\hline 4 & Have emotional depth & 4 & Mediocre relationship \\
\hline 5 & $\begin{array}{c}\text { Easy to work with and } \\
\text { personal }\end{array}$ & 5 & More formal and impersonal \\
\hline
\end{tabular}


In addition, by Parta Ibeng (2021), based on a person's perspective on a group with various aspects that surround his life, the group is distinguished, including: 1) In-group, namely all groups where a person feels he is a member and also expects recognition, loyalty, as well as help, and 2) Out-group, namely all groups in which a person feels not a member and may also show hostility, peaceful competition, or simply feel different.

In-group and out-group are separated in a hostile relationship. Individuals in the ingroup members refer to the group or themselves as "we", and also refer to the individual members of the out-group as "them". This enmity within the in-group and also out-group tends to have a cultural atmosphere. Examples are such as, between immigrants and natives, between communities, to hostility based on an SARA.

\subsection{Definition of General Politics}

According to Aris Kurniawan (2021), politics is an attempt to achieve a good life. In Indonesia, we remember the saying gemah ripah loh jinawi. Political science is the study of politics or politics or politics. Politics is the pursuit of a good life. In Indonesia, we remember the saying gemah ripah loh jinawi. The Ancient Greeks, especially Plato and Aristotle, called it en dam onia or the good life.

Etymologically, politics comes from the Greek "polis" which means city with state status. In general, the term politics can be interpreted as a variety of activities in a country which involves the process of determining the goals of the system and carrying out those goals.

According to Miriam Budiardjo, et al (1976), the term politics in the political science literature can be understood from various definitions. It should be pointed out that the differences that arise between one definition and another are actually only caused by the fact that each scholar only looks at one aspect of politics. This aspect is then used as the main concept in analyzing other aspects. In general it can be said that politics are various activities in a political system or state which involve the process of determining the goals of the system, and how to carry out its goals.

Heywood defines politics broadly as the whole activity in which people make, maintain and amend the general rules in which they live. Decision making about what the goals of the political system or country are cannot be separated from choosing between several alternatives and determining the order of priorities. Meanwhile, to carry out these objectives, public policies concerning the regulation and distribution or allocation of existing resources are needed.

\subsection{Local Politics}

According to Leo Agustino and Mohammad Agus Yusoff (2010), the dramatic changes in Indonesian politics since the fall of the Suharto regime have made room for a real democracy. Local politics becomes more open and becomes a determinant of development in the region. There are at least two conditions to be described in relation to local politics in Indonesia, as follows:

1) Local Politics before Reformation: Roots and Gait of Local Strong People The dynamics of local politics in Indonesia are changing all the time. In the era before independence, local politics in the archipelago showed a blurry portrait because the rulers obtained power within the totalitarian framework of customary law. As a result, most layers of society were only recognized as servants (not citizens) who were never the subject of development at that time. 
People are made objects of political life that is not on their side. Various forms of taxes and tributes were withdrawn by the authorities through their repressive apparatus which made the economic condition of the people worse off. The inhumane treatment of the ruler then sparked popular resistance. Stories or myths about local strongmen such as Ken Arok, Samin, Pitung and others, who try to fight against the center of power reflect some of the many forms or desires of civil disobedience in the past.

Local politics in Indonesia became more dynamic after the proclamation of independence, when community power began to seep into formal institutions. This situation is more or less a positive legacy of the Dutch colonial design to provide opportunities for ordinary people to be involved in politics in the context of implementing ethical politics.

As a result, the traditional elites (regional aristocrats) had to compete with the general public who were also trying hard to gain positions in state institutions. In addition to the competition between the traditional elite and the common people that emerged after the proclamation, the issue of ethnicity is also prominent in the framework of nation-building in Indonesia. Political tensions with ethnic nuances increased rapidly during the Parliamentary Democracy (1950-1958) and guided democracy.

2) Local politics of the reform order: the illusion of change. When the monetary crisis hit Indonesia in 1997, in the not too distant future, a political explosion detonated by the student movement succeeded in destroying central power in Jakarta. The collapse of the New order also marked a new polycentrism that rejected central power (decentring).

They can no longer be brokers for central interests in the regions. Or, they can no longer be the sole rulers in the regions because political polycentrism has defeated the logic of political centralism. The change of direction from a centralized and controlled 'old politics' to a decentralized and egalitarian 'new politics' brought fresh air to local politics in Indonesia, at least in the first years of reform.

However, after going through a brief reform 'honeymoon', some scholars soon caught on to the rapid growth of political brokers and local strongmen at the local level, who began to take over the vacuum and strengthen their access to control over local politics. The brokers and local strongmen who took over the void of players in the local political arena during the Reformation Order were usually 'old brokers' who in the past were unable or did not get the opportunity to compete with local strongmen who supported the New Order regime.

Furthermore, Yeremias Tomoning (2005), local politics can simply be defined as all political activities that are at the local level. In this case, all matters related to politics such as local government, the formation of regional policies, as well as regional head elections.

This shows that the scope of local politics is below the national one. Regional groups included in the management of local politics include cities, districts and villages. At the local political level, the national government cannot fully intervene. This is because each local order has its own local regulations.

In this case, local regulations are usually not always in line with the government. Regulations that are not in line with the government include sharia regulations. At the national political level, there are no known sharia-based regulations, but at the local level, sharia regulations can be created. This is due to the existence of regional autonomy which frees regions to develop their own territory. 
Indirectly, the national government assumes that the regions understand their own territory better so that they are given the freedom to regulate their territory. Freedom to regulate territory at the local level does not mean free to oppose the state. The implementation of local politics must also be in line with national politics.

The difference in regional level does not mean that it must be separated from the national regional order, but local politics must still be oriented to national politics. National politics is still a mandatory reference for local politics. The thing that is used as an example of national politics is the election of regional heads. In the national order, the election of the head of government is the presidential election, but at the local level the mayor, regent and village head are elected.

In this case, although the coverage area is different, the process of selecting regional heads is still in accordance with the process of selecting national leaders. This can be seen from the electoral system that uses elections. At the local level, it is also obligatory to use elections at the time of the regional head election, but with different participants. In the national order, it requires the participation of citizens from all over Indonesia, but at the local level, it is sufficient for the natives of the area or those who have settled in the area.

\subsection{Understanding Conflict}

According to Ellya Rosana (2015), Humans are conflicting creatures, namely creatures who are always involved in differences, contradictions, and competition either voluntarily or forced. This cannot be avoided because it is a permanent aspect of social life. Conflict at a certain level is needed as a means of changing humans as members of society to be better.

The contemporary view of conflict is based on the assumption that conflict is something that is inevitable as a logical consequence of human interaction. The emergence of conflict departs from the condition of the plurality of the structure of society and conflict is a phenomenon that often occurs throughout the process of human life. The emergence of conflict departs from the condition of the plurality of the structure of society and conflict is a phenomenon that often occurs throughout the process of human life.

Conflicts are generally based on differences. Differences themselves are an inseparable part of the reality of life. Differences can be a potential problem. It becomes potential if it is well understood and managed constructively to enrich the meaning of life. It can become a problem if it later develops into a form of settlement by means of violence.

Ellya Rosana (2015) stated that in sociology, we recognize the existence of a conflict theory that seeks to understand conflict from the point of view of social science. Conflict theory is a theory that views that social change does not occur through a process of adjusting values that bring about change, but occurs as a result of conflicts that result in compromises that are different from the original conditions.

Conflict theory was born as an antithesis of structural functional theory which views the importance of order in society. This conflict theory was built in order to directly oppose the structural-functional theory, because it is not surprising that the propositions put forward by its adherents contradict the prepositions contained in the structural-functional theory. 


\section{Results and Discussion}

This discussion step will include various views of selected informants, and are considered to know a lot about the dynamics and developments of politics in general and local politics. Specifically regarding local politics, what is meant in this study is the national political parties that compete in the Kampar Riau area, then how do the Kampar people respond to this.

This means that the portion of the response process is emphasized on the social aspect in the process of providing support. a group of communities that will be used as the terminology for determining the provision of support later by looking at the basic associations of people, tribes, clans and communities where they live as a result of historical unity. The understanding of the breakdown of the main problems as formulated above, will be described one by one with different informants in the form of interviews with some narratives that are considered important, as below:

Informant 1: Member of a Party ( Name Does Not Want to Be Mentioned)

To what extent are the challenges of the horizontal conflict in Kampar Riau, from the perspective of local politics and society? 


\begin{tabular}{|c|c|}
\hline 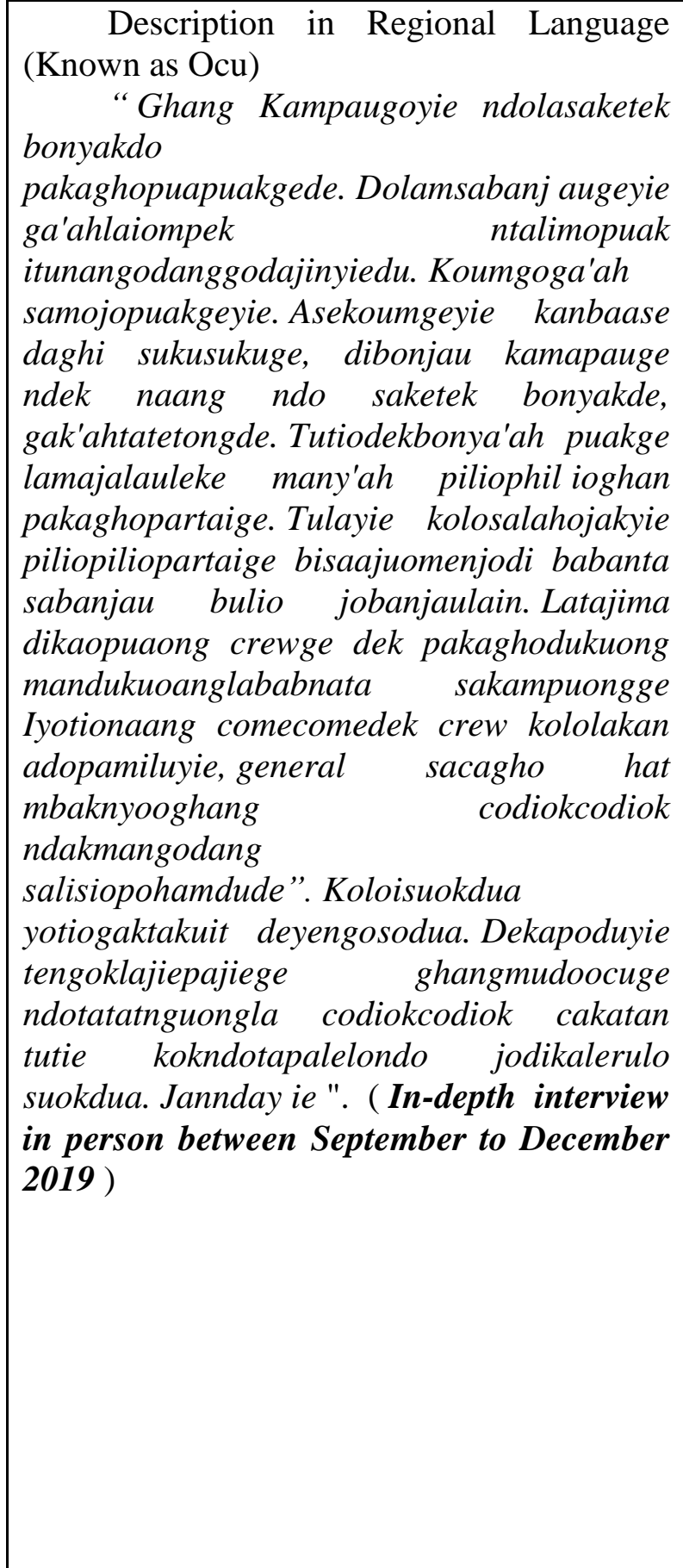 & $\begin{array}{l}\text { Description in Indonesian } \\
\text { In the Kampar area there are } \\
\text { many people, tribes and clans which } \\
\text { can be interpreted as tribes. Many of } \\
\text { these tribes are closely related to the } \\
\text { Kampar community which consists of } \\
\text { many tribes, there are ethnic origins } \\
\text { there are also immigrant tribes but } \\
\text { have been domiciled for a very long } \\
\text { time, in reality they are considered } \\
\text { native people called the Ocu people. } \\
\text { There will be problems that arise in } \\
\text { the community that are triggered by } \\
\text { differences in the choice of political } \\
\text { parties, especially during the election } \\
\text { period, this is justified. In fact, there is } \\
\text { a link between the religious } \\
\text { community and the existence of local } \\
\text { politics in the Kampar area, but the } \\
\text { upheaval of horizontal conflicts that } \\
\text { are worrying seems to have not } \\
\text { happened yet. This situation is due to } \\
\text { the leadership of the tribe, clan, tribe, } \\
\text { which is still responsive and includes } \\
\text { the readiness of the security forces, of } \\
\text { course. In addition, I see that in the } \\
\text { future, the existence of religious } \\
\text { groups in the implementation of } \\
\text { elections in the regions is quite } \\
\text { worrying, this is due to several } \\
\text { phenomena that are currently } \\
\text { emerging, especially seeing the } \\
\text { dynamics of the young generation of } \\
\text { Ocu people who are increasingly } \\
\text { aggressive. The aggressiveness of } \\
\text { young people is actually a positive } \\
\text { thing, I hope it doesn't happen the } \\
\text { other way around. }\end{array}$ \\
\hline
\end{tabular}

Informant 2 : Member of the Kampar People's Legislative Council (DPRD) ( Name not to be mentioned)

How far Challenges Conflict harizontal In Kampar Riau, Seen From the aspect of communalism and politics Local ?

\begin{tabular}{|l|l|}
\hline $\begin{array}{l}\text { Description in Regional Language } \\
\text { (Known as Ocu) }\end{array}$ & $\begin{array}{l}\text { Description in Indonesian } \\
\text { The name of the village, of course, }\end{array}$ \\
$\begin{array}{l}\text { "nomonyokampungge laobela baghagam } \\
\text { ghangdoidolamnyoyie. Apodekcondoitudu, }\end{array}$ & $\begin{array}{l}\text { a variety of colorful people who live } \\
\text { in it. This diversity is a result of the }\end{array}$ \\
\hline
\end{tabular}


lajolela dekbanyaklosusku, puak-puakge, kamuge, gak'ah kolodiituongitung dokekga'ah mopuluanyie. Topic ghangocugeka ghamailoma lowetio banjoukampauge tuuntuongdeklababagi ompektangma. Sabagiturokanhulu,

sabagile tu rokaniliu, sabagile tu palalawanma, tuciekle kampauasalge. Tulowejuolema

laterongege tutiodek baghagamjuo lenagoghikampauge. Pakaghopolitikge

yie, yotie mambaib many comecome banjaugodeeh, yotie nanyiok joangekketek dekpolitikge. Mamamsionongkuam

masiongmasionglo nandipiliode'eh tontula angek cocky apolaiyie lailo kompyie tula is a bit of a duma naang. Iyotie adotalipahubuong antagho perkaumange jo adonyopartaige in Kamparge deyenbonaukand ua."

(In-depth interview in person between September to December 2019 ) diversity of tribes, tribes, clans with a fairly wide area as well. Even then, the division of the Kampar area has been divided into four regencies, including: 1) Rokan Hulu Regency, 2) Rokan Hilir Regency, 3) Palalawan Regency, and 4) the Parent Regency, namely the original Kampar Regency. It is confirmed that there is a strong relationship between the existence of religious groups and the emergence of hot temperatures leading to conflict in this area which is related to local politics. You can imagine the number of political parties participating in the contest in Kampar, faced with many clans, tribes, and tribes throughout the Kampar area. Of course there will be friction here and there. Each party may have a different choice of party, especially if there is a campaign activity, it will be quite disturbing for us, afraid that a serious shift will occur.

\begin{tabular}{|l|l|}
\hline $\begin{array}{r}\text { Informant 3: Kampar State Civil Apparatus ( Name Doesn't Want To Be } \\
\text { Mentioned) }\end{array}$ \\
To what extent are the challenges of the horizontal conflict in Kampar \\
Riau, from the perspective of local politics and society?
\end{tabular}

Informant 4: Educated / Kampar Students (Junaidi)

To what extent are the challenges of the horizontal conflict in Kampar 


\begin{tabular}{|c|c|}
\hline \multicolumn{2}{|c|}{ Riau, from the perspective of local politics and society? } \\
\hline 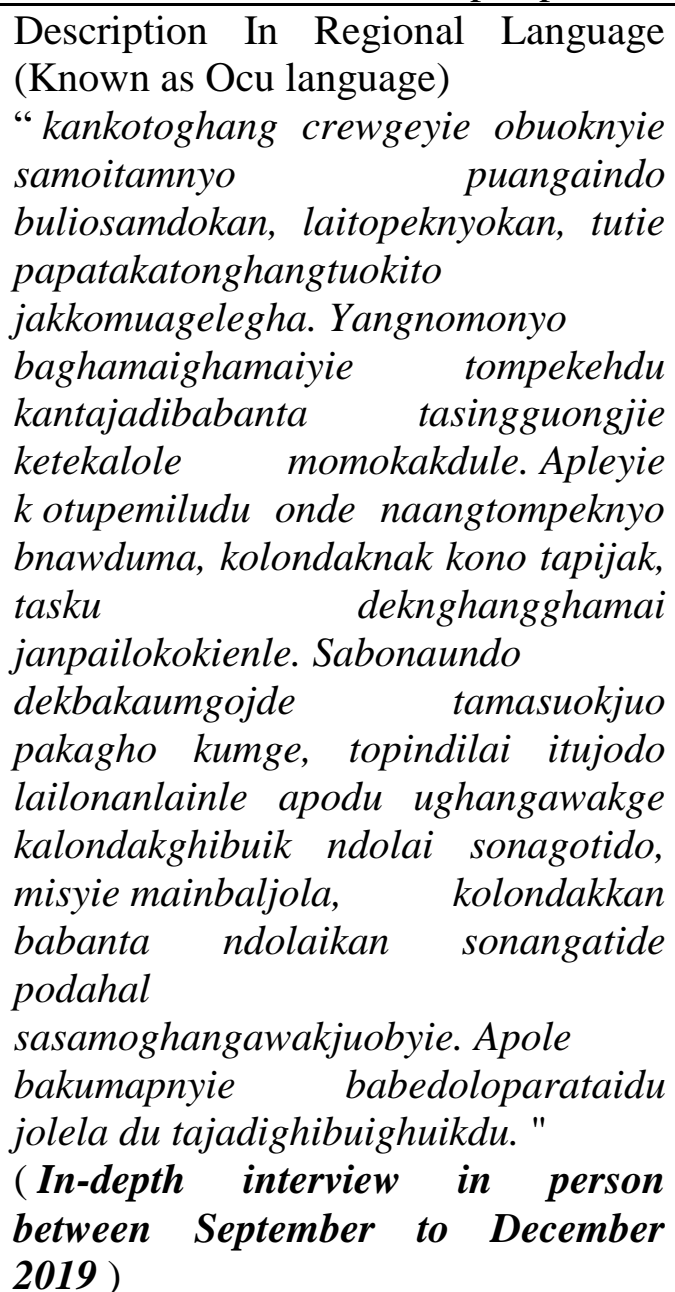 & $\begin{array}{l}\text { Description in Indonesian } \\
\text { As our parents said before, } \\
\text { which stated that hair is the same as } \\
\text { black, behavior and character are still } \\
\text { different from one another. A crowd } \\
\text { ( an activity ) which is attended by a } \\
\text { lot of people, of course, will have the } \\
\text { opportunity for friction to occur, } \\
\text { compared to an activity that does not } \\
\text { invite a lot of people. I confirm that } \\
\text { local political events, such as the } \\
\text { holding of elections, are one of the } \\
\text { doors to open a kind of open conflict } \\
\text { between the children } \\
\text { and grandchildren of the Ocu } \\
\text { people. Why did this happen, because } \\
\text { it turns out that the choice of a } \\
\text { political party has been given a signal } \\
\text { first by the leaders of the clans, their } \\
\text { respective clans. Often the choice with } \\
\text { the clan is closely related to the } \\
\text { interests of their village development, } \\
\text { such as repairing roads, bridges, } \\
\text { mosques, and others. }\end{array}$ \\
\hline
\end{tabular}

\begin{tabular}{|c|c|}
\hline he perspec & \\
\hline $\begin{array}{l}\text { Description in Regional } \\
\text { Language ( Known as Ocu) } \\
\text { "iyotioma ghangocuge } \\
\text { saketeksaketek nakbapoghngjie, not } \\
\text { obedekdo basoghakghangpantangge } \\
\text { manengokkolokuan } \\
\text { ghangawakge. Tumisie kotupailudu, } \\
\text { tompekughanganokonokjonyie look at } \\
\text { ghangminangtan biala mamalioparty } \\
\text { ndaksamodo topitot apiyo basatu, tutie } \\
\text { ughangdu } \\
\text { amdapeknyo. ntaaponansala ga'ahge } \\
\text { gang crew, cubitiwu ghangminangdua } \\
\text { buliowak mandapekloyie. When the } \\
\text { party is nanbapilio bedo topiwak } \\
\text { janbakalade. Tutuie }\end{array}$ & $\begin{array}{l}\text { Description in Indonesian } \\
\text { I confirm that these Ocu Kampar } \\
\text { people will easily disagree when the } \\
\text { choice of local parties is different. } \\
\text { Each group may have a choice of a } \\
\text { party in a different election, but the } \\
\text { process often ends in disagreement. } \\
\text { Let's learn from the Minangkabau } \\
\text { people, even though they have } \\
\text { different preferences for their political } \\
\text { party, they are still solid, so they often } \\
\text { get the fortune of development. Mri, } \\
\text { the attitude is like we will change the } \\
\text { implementation of the upcoming } \\
\text { elections, remember my message is } \\
\text { for all Ocu people. }\end{array}$ \\
\hline
\end{tabular}




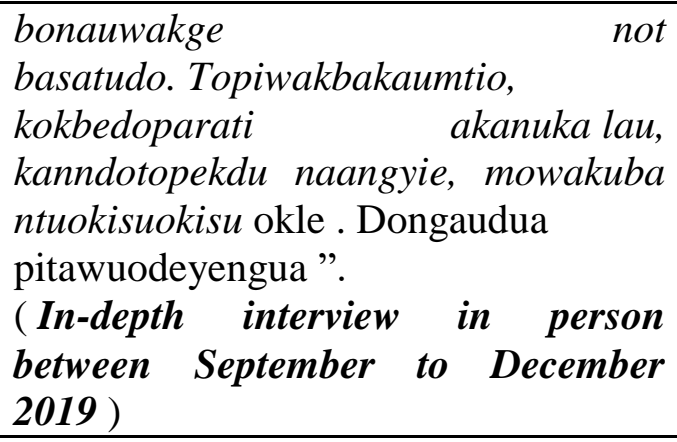

\section{Conclusion}

The results of the analysis carried out on the views of informants regarding the formulation of the problem to what extent the challenges of the horizontal conflict in Kampar Riau, seen from the social and local political aspects, can be formulated as follows: 1) In reality, conflict is sometimes unavoidable in human social relations, both between individuals. With individuals, individuals with groups, groups with groups. 2) In the context of the challenges of the horizontal conflict in Kampar Riau, seen from the social and local political aspects, it is basically true. It turns out that the ethnic aspect also has a role in the emergence of horizontal conflicts. 3) the social aspect and local politics are two aspects that mutually allow the emergence of horizontal conflicts, so that there is a need for awareness of every clan, tribe, or ethnic group to have awareness about there is no need to conflict with the reasons for choosing a political party. 4) The tribal conflicts that have occurred so far are considered to be still in their early stages in the sense that they can still be suppressed, managed with a cultural approach based on the community itself.

\section{References}

Abdulkadir B. Nambo, dkk. 2005. Memahami Tentang Beberapa Konsep Politik (Suatu Telaah Dari Sistem Politik), Volume XXI No. 2 April - Juni 2005 : 262 - 28, Dalam https://media.neliti.com/media/publications/154709-ID-memahami-tentangbeberapa-konsep-politik.pdf

Aris Kurniawan, 2021. Pengertian Ilmu Politik - Pendekatan, Hubungan, Aspek, Konsep, Kekuasaan, Para Ahl, Dalam https://www.gurupendidikan.co.id/pengertian-ilmupolitik/

Azhar, A. (2018). Marketing of Political Communication Created by National Mandate Party (PAN) in General Election 2005-2015, North Sumatra, Indonesia. Budapest International Research and Critics Institute (BIRCI-Journal), 93-106.

Budiono K. 2000. Kebhinnekaan masyarakat Indonesia, suatu problemat ifilsafat di Indonesia (dlm) Clifford Geerzt. Gramedia Widiasarana Indonesia: Jakarta.

Cahya Dicky Pratama, 2020. Kominutas Dalam Perspektif Sosiologi. Dalam https://www.kompas.com/skola/read/2020/12/07/182940069/komunitas-dalamperspektif-sosiologi?page $=$ all

Ellya Rosana, 2015. Konflik Pada Kehidupan Masyarakat (Telaah Mengenai Teori Dan Penyelesaian Konflik Pada Masyarakat Modern), Dalam Al-AdYaN/Vol.X, No.2/JuliDesember $/ 2015$

Gibson, James L., et al., 1977. Organisasi: Perilaku, Struktur, Proses. Alih bahasa oleh Adriani. Jakarta: Binarupa Aksara, Dalam Mohamad Muspawi, 2014. Manajemen 
Konflik (Upaya Penyelesaian Konflik Dalam Organisasi), Dalam Volume 16, Nomor

2, Hal. 41-46, ISSN:0852-8349

Hildred. Geertz. 1981. Aneka Budaya dan Komunitas Di Indonesia, Yayasan Ilmu-Ilmu Sosial \& FIS - Universitas Indonesia: Jakarta.

Hasan. Shadily. 1961. Sosiologi Untuk Masyarakat Indonesia, Jakarta: PT. Pembangunan. Homans 1950. Pengertian Kelompok, Dalam Parta Ibeng, 2021, Pengertian Kelompok, Contoh, Jenis, Perbedaan dan Menurut Ahli, Dalam https://pendidikan.co.id/pengertian-kelompok-contoh-jenis-perbedaan-dan-menurutahli/

Irwandi, Endah R. Chotim, 2017. Analisis Konflik Antara Masyarakat, Pemerintah Dan Swasta (Studi Kasus Di Dusun Sungai Samak, Desa Sungai Samak, Kecamatan Badau, Kabupaten Belitung), Jispo Vol. 7 No. 2 Edisi: Juli-Desember Tahun 2017.

Joseph De Vito 1997. Pengertian Kelompok, Dalam Parta Ibeng, 2021, Pengertian Kelompok, Contoh, Jenis, Perbedaan dan Menurut Ahli, Dalam https://pendidikan.co.id/pengertian-kelompok-contoh-jenis-perbedaan-dan-menurutahli/

Junus Melalatoa, 1995. Suku Bangas Di Indonesia. Jilid L-Z Departemen Pendidikan Dan Kebudayaan,Dalamhttps://books.google.co.id/books?id=FbGECgAAQBAJ\&printsec $=$ frontcover $\& \mathrm{hl}=\mathrm{id} \# \mathrm{v}=$ onepage $\& \mathrm{q} \& \mathrm{f}=$ false

Kamus Besar Bahasa Indonesia, 2020. Arti Kata Perkauman, Dalam https://ceklengkap.com/arti-kata-perkauman-adalah-kamus-kbbi/

Konsep Perkauman, Dalam https:// rencanailmusfy. wordpress. com/ konsepperkauman/

Leo Agustino dan Mohammad Agus Yusoff, 2010. Politik lokal di Indonesia: dari otokratik ke reformasi politik, Jurnal Ilmu Politik, Edisi 21, 2010, Dalam https://aipipolitik.org/attachments/article/54/3_Politik\%20Lokal\%20di\%20Indonesi a_Leo\%20Agustino_Jurnal\%20AIPI_No.21\%20Thn\%202010.pdf

Miriam Budiardjo, dkk, 1976. Ilmu Politik : Ruang Lingkup Dan Konsep (Modul 1), Dalam http://repository.ut.ac.id/4210/1/IPEM4215-M1.pdf

Mahmudi Siwi, 2012. Konsep Komunitas dan Masyarakat Dalam Perspektif Sosiologi, 2012. Dalam https://skpm.ipb.ac.id/konsep-komunitas-dan-masyarakat-dalamperspektif-sosiologi/

Manao, H. (2020). Political Reposition of Authority in South Nias DPRD Members in 2014 Election (A Study on Social Construction of Peter L. Berger). Budapest International Research and Critics Institute-Journal (BIRCI-Journal) Volume 3, No 1, Page: 262-269.

Merton, pengertian kelompok, Dalam Parta Ibeng, 2021, Pengertian Kelompok, Contoh, Jenis, Perbedaan dan Menurut Ahli, Dalam https://pendidikan.co.id/pengertiankelompok-contoh-jenis-perbedaan-dan-menurut-ahli/

Mohamad Muspawi, 2014. Manajemen Konflik (Upaya Penyelesaian Konflik Dalam Organisasi), Dalam Volume 16, Nomor 2, Hal. 41-46 Issn: 0852-8349

Parta Ibeng, 2021, Pengertian Kelompok, Contoh, Jenis, Perbedaan dan Menurut Ahli, Dalam https://pendidikan.co.id/pengertian-kelompok-contoh-jenis-perbedaan-danmenurut-ahli/

Rohani Binti Mamat, 2017. Isu Perkauman Di Malaysia (Isu-Isu Negatif Perkauman Di Malaysia Perlu Dibendung Untuk Mengelakkan Masalah Hubungan Etnik Dan Kaum, Dalam http://Nikmeng.Blogspot.Com/ 
Soerjono Soekanto, 2006. Konflik Sosial, Dalam Irwandi, Endah R. Chotim, 2017. Analisis Konflik Antara Masyarakat, Pemerintah Dan Swasta (Studi Kasus Di Dusun Sungai Samak, Desa Sungai Samak, Kecamatan Badau, Kabupaten Belitung), Jispo Vol. 7 No. 2 Edisi: Juli-Desember Tahun 2017.

Wirawan, 2010. Konflik dan Manajemen konflik: Teori, Aplikasi, dan Penelitian. Salemba Empat, Jakarta. Dalam Mohamad Muspawi, 2014. Manajemen Konflik (Upaya Penyelesaian Konflik Dalam Organisasi), Dalam Volume 16, Nomor 2, Hal. 41-46 Issn:0852-8349.

Yeremias Tomoning, 2005. Politik Lokal Di Tingkat Desa (Studi Kasus Pelaksanaan Peraturan Pemerintah No 72 Tahun 2005 Tentang Desa Dalam Pemilihan Kepala Desa Di Desa Minton Tahun 2013 Kecamtan Taliabu Utara Kabupaten Pulau Taliabu Propinsi Maluku Utara), Dalam https://media.neliti.com/media/publications/1060ID-politik-lokal-di-tingkat-desa1-studi-kasus-pelaksanaan-peraturan-pemerintah-no7.pdf 